\title{
ISLAM POPULER DI MEDIA MASSA
}

\author{
Oleb:Musnur Hery*
}

\section{Abstract}

Todays, the power of mass media cannot be avoided. It is able to influence and form the public opinion. The influence is also on various aspects of life, including the people' religious life. This religious life has been coloring the mass media. This fact indicates that the religious life may become one of the interesting programs which can be sold and conomically valuable. As a result, religion is no longer in the form of preacbing and delivering good or bad behaviours. Religion will become more dynamic and flexible. Consequently, the focus is not on the importance of the religion, but on the role and performance of the figures and the relativity of the showe. Thus, religion becomes popular. The religion-based drama is conducted by the religious figures and their followers. The use of drama provides that religion is merely a popular show; therefore it becomes difficult to attain the realities.

مستخحص

لا يمكن الشك اليوم في قوة وسائل الإعلام ومقدرةا على تشكيل الرأي العام في مناح حياتية شتى، بما فيها المجال الديين. وفي نفس الوقت، لا تتورع ومائل الإعلام اليوم عن استخدام البرامج الدينية لاستدرار المنافع الاقتصادية. وفي سبيل استدرار تلك المنافع تحاول وسائل الإعلام تشكيل رأي عام عن اللحياة الدينية أكثر نسبية وأقل صرامة من الشكل التقليدي للتدين. إن الدين يتحول اليوم في وسائل الإعلام إلى ظاهرة مسرحية

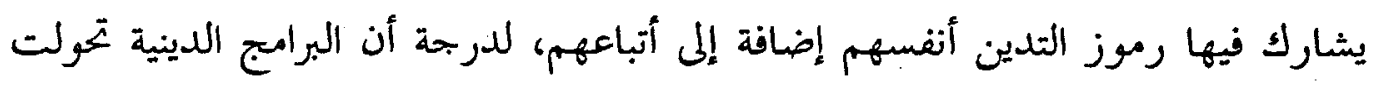

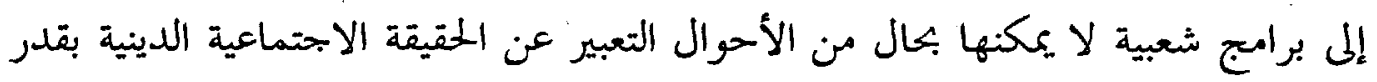
ما يتحول همها إلى إرضاء العميل، سواء المعلن أو المشاهد

\section{A. Pendahuluan}

Seorang tokoh agama, memakai sorban terlilit di leher dan berbaju koko. Ia duduk dengan manisnya di sebuah kursi sofa. Disebelahnya duduk seorang presenter,

•Dosen Pascasarjana IAIN Raden Fatah Palembang. Email: musnur.hery@gmail.com 
juga memakai baju koko dan berpeci. Mereka berbincang-bincang soal agama Islam, bagaimana tuntunan kehidupan sehari-hari harusnya dilakukan dan bagaimana menggapai taqwa. Pada saatnya nanti diadakan interaktif dengan khalayak melalui telepon. Itulah salah satu gambaran kehadiran agama dalam lembaga penyiaran. Pola tersebut bisa dikatakan masih bersifat konvensional, artinya dari zaman dulu kehadiran media penyiaran televisi, maka tampilannya tetap seperti itu.

Sementara dalam kesempatan lain, seorang tokoh agama tampil dalam sebuah acara hiburan. Musik ditampilkan bernuansa islami, sang ustazd menyampaikan beberapa hikmah kehidupan yang kira-kira memiliki hubungan dengan lagu yang diputar. Hakekatnya juga berdakwah, namun polanya yang sedikit berbeda. Dalam hal ini, tokoh tadi sudah menggunakan pola hiburan dalam dakwahnya. Ia ingin melakukan sesuatu yang tidak lagi dalam pola yang serius.

Dalam konteks lain, saat acara televisi memasuki bulan ramadhan, maka tampillah di televisi semua yang berbau Islami. Presenternya tampil dengan dandanan yang katanya Islam, berjilbab ataupun berbaju koko. Saat itu ia memainkan peran sebagai seorang muslim di bulan yang sakral. Demi menghormati ramadhan, maka dandanan harus dirubah. Selepas ramadhan ia kembali lagi seperti biasa. Yang menarik lagi adalah tayangan-tayangan infotainment yang meliput aktifitas dan gosipgosip seputar para selebritis. Jika seorang artis ditanya tentang gosip seputar skandal kehidupan pribadinya, artis yang hanya memakai tanktop tersebut dengan mudahnya berkata bahwa "biarlah, semua itu terserah yang di Atas". Kata-kata di "Atas" jelas menunjukkan pada keyakinan agama seorang (biasanya ini identik dengan Islam).

Seorang artis, seorang tokoh agama, masyarakat biasa, ketika tampil di layar kaca, maka mereka akan mulai bermain peran. Saat itu peran mereka disesuaikan dengan topik dan tema yang diangkat. Terkadang menjadi sulit untuk menentukan peran sebenarnya yang diangkat dan dilakukan oleh seseorang. Relatifitas menjadi sangat biasa, dan inilah yang kerap terjadi dalam lembaga penyiaran. Islam kemudian juga memperlihatkan nilai-nilai yang bisa saja menjadi relatif. Dalam hal ini nilainilai budaya populer sudah masuk dan kemudian berinteraksi dengan mekanisme yang berlaku dalam lembaga penyiaran. Mekanisme budaya populer memang pada dasarnya sesuatu yang melekat pada media massa.

\section{B. Konsep Budaya Populer}

Budaya populer (popular culture) memang lahir dan dibesarkan oleh media massa. Kekuatan sebuah media, terutama media penyiaran, mampu menghadirkan budaya- 
budaya baru serta nilai-nilai baru. Pada masanya nanti media juga mampu melakukan penetrasi-penetrasi yang akan mempengaruhi budaya yang sudah ada, sehingga terjadi proses hegemoni dan terkadang menghilangkan budaya yang sudah ada.

Proses masuknya sebuah budaya populer tentu berkaitan dengan kekuatan media itu sendiri. Secara teoritis, kekuatan media menjadi faktor penentu masuk dan berkembangnya budaya populer. Kekuatan media kemudian akan dipengaruhi secara signifikan oleh sistem sosial politik yang berlaku di negara bersangkutan. Biasanya semakin diakuinya kebebasan individu dan kekuatan bersama, maka semakin tinggi pula penetrasi budaya terhadap masyarakat.

Media sendiri sangat signifikan dalam merepresentasikan identitas kepada pihakpihak lain, bahkan kepada kelompok berbeda budaya. Media mampu menjangkau lokasi-lokasi yang mungkin sangat terbatas untuk didatangi. Walter Lippman menjelaskan apa yang disebut sebagai lingkungan semu. Dunia objektif yang dihadapi manusia itu "tidak terjangkau, tak terlihat, dan tak terbayangkan." Oleh karenanya, manusia menciptakan sendiri dunianya dalam upaya memahami sedikit dunia objektif tersebut. Oleh karena itu, perilaku manusia bukanlah kenyataan yang sesungguhnya, tapi yang diciptakan. Media massa kemudian sangat berperanan sekali dalam menciptakan realitas tersebut. Hal inilah yang kemudian disebut oleh Baudrillard sebagai simulacrum, realitas yang terbentuk seolah-olah menyerupai realitas yang asli. ${ }^{2} \mathrm{Hal}$ ini menegaskan bahwa realitas yang ada sebenarnya diciptakan, bukan tercipta dengan sendirinya. Budaya populer berada pada posisi ini, hadir karena dikonstruksi dan diciptakan melalui media.

Gagasan budaya populer terkait dengan perselisihan atas makna dan interpretasi yang mendahului menjadi tampak menonjol dalam perdebatan soal budaya massa. ${ }^{3}$ Budaya massa sendiri adalah budaya populer yang diproduksi untuk pasar massal. Pertumbuhan budaya ini berarti memberi ruang sempit bagi segala jenis kebudayaan yang tidak dapat menghasilkan uang, yang tidak dapat diproduksi secara massal seperti halnya kesenian dan budaya rakyat. Memassalkan sebuah budaya berarti memerlukan sarana, maka media massa memegang peranan penting.

Logika menarik dari budaya ini adalah penentu utamanya yaitu keuntungan produksi dan pemasaran yang dapat dihasilkan dari potensi pasar massalnya. Dominic

${ }^{1}$ Walter Lippman, Public Opinion, (New York: Free Press, 1965), hal. 54.

${ }^{2}$ Baudrillard dalam Yasraf Amir Piliang, Posrealitas, (Yogyakarta: Jalasutra, 2003), hal. 55.

${ }^{3}$ Dominic Strinati, Popular Culture, Pengantar Menuju Teori Budaya Populer, (Yogyakarta: Penerbit Bentang, 2003), hal. 3. 
Strinati menegaskan bahwa jika budaya massa tidak bisa menghasilkan uang, mungkin tidak akan diproduksi. ${ }^{4}$ Artinya disini, kekuatan sebuah budaya massa ataupun budaya populer sangat ditentukan oleh dorongan materi yang senantiasa mengikutinya. Sekali lagi budaya ini sangat membutuhkan kehadiran media massa.

Budaya populer memiliki keunggulan yaitu kemampuannya dalam mempengaruhi khalayak secara luas dan menyeluruh. Budaya yang melekat pada media ini ternyata mampu menciptakan sebuah gaya-gaya tertentu yang menjadi daya tarik tersendiri, melalui kekuatan audio visualnya. Ia bisa menciptakan sebuah realitas yang kemudian mempengaruhi khalayak dengan kuat.

Budaya ini bisa memberikan pengaruh kuat karena memang pada awalnya ia adalah produk-produk kultural yang kemudian dikembangkan oleh kekuatan media massa. Akan tetapi, karena lahirnya masyarakat massa dan budaya massa terjadi kekurangan sumber daya intelektual maupun moral. Khalayak tidak dapat memikirkan alternatif-alternatif lain, bidang budaya kemudian direduksi menjadi sebuah budaya massa umum. ${ }^{5}$

Dalam hal ini perlu dipahami keterkaitan budaya dengan suatu kelompok budaya. Setidaknya ada lima komponen yang mendefinisikan gagasan tentang budaya bagi anggota suatu kelompok budaya yaitu:

1. Suatu khazanah kepercayaan yang melaluinya anggota kelompok tersebut memahami diri mereka sendiri dan dunia, serta menerapkan makna terhadap prilaku dan hubungan sosialnya;

2. Pelbagai nilai dan norma prilaku yang mengatur hubungan sosial, menginformasikan ide-ide tentang "kebaikan", dan ada di belakang peristiwa kehidupan yang pokok seperti kelahiran, pernikahan, dan kematian.

3. Pelbagai ritual dan seni ekspresif yang mengkomunikasikan pemahaman diri, pengalaman, dan emosi kolektif.

4. Pelbagai konsepsi tentang sejarah yang berbeda dan tentang perbedaan dari kelompok-kelompok lain.

5. Pengembangan karakter sosial bersama (termasuk unsur-unsur seperti motivasi dan temperamen)

Apa yang ditegaskan di atas, pada hakekatnya kemudian mampu digeser oleh kehadiran budaya massa. Inilah yang dikatakan oleh Burton bahwa budaya massa telah

${ }^{4}$ Ibid, hal. 7.

s Ibid hal. 12. 
menggantikan budaya rakyat (folk culture), yang sebenarnya adalah budaya masyarakat yang paling mendasar. ${ }^{6}$ Budaya massa sendiri didominasi oleh produksi dan konsumsi barang-barang material bukan oleh seni-seni sejati dan hiburan masyarakat.

Dennis Mc Quail juga menegaskan hal yang sama. Budaya populer atau lebih diidentikkan sebagai low culture akan menggantikan budaya rakyat yang sebenarnya adalah bigh culture. ${ }^{7}$ Inilah proses yang terjadi. Budaya mendasar lambat laun digeser melalui kekuatan budaya popular melalui senjata terkuatnya media massa. Kekuatan media memang menjadi senjata yang ampuh untuk menghancurkan sendi-sendi kehidupan bersama di sebuah masyarakat.

Secara teoritis, media memang memiliki karakteristik mampu mempengaruhi khalayak. Pengertian dari sisi komunikasi massa menyebutkan bahwa mereka memang memiliki karakteritisk yang khas, yaitu bersifat serentak, cakupan luas, dapat ditangkap secara bersamaan, dan memiliki keunggulan audio visual. Khas bentuk ini mampu menciptakan sebuah opini publik tertentu.

Keunggulan media massa memang sebuah kenyataan yang tak bisa dipungkiri. Secara teoritis, pendekatan Agenda Setting menyebutkan bahwa pada dasarnya media memiliki agenda tersendiri. ${ }^{8}$ Agenda media ini biasanya didasarkan atas kenyataan bahwa publik memiliki agenda tersendiri yang kemudian direduksi pada agenda media. Media sendiri mampu menciptakan agenda publik melalui penetrasi yang dilakukannya. Pada akhirnya, agenda yang diusung oleh media akan menjadi agenda publik secara umum. Disinilah media mampu melakukan upaya-upaya pencitraan sehingga agenda tersebut bisa berkembang secara lebih luas.

Khalayak sendiri, sebagaimana dijelaskan oleh Wahyu Wibowo, ${ }^{9}$ akan menjadi komunitas yang tragik, lemah dalam mengkritisi, dan cenderung terbuai oleh terpaanterpaan media. Masyarakat tragik ini biasa terjadi dalam konteks masyarakat urban cosmopolit, yaitu kelompok masyarakat yang tidak biasa keluar dari jeratan godaan modernisasi. Pada akhirnya mereka akan terjebak dalam lingkaran ketat hedonisme budaya.

Secara praktis hal ini bisa dijelaskan dalam realitas sehari-hari. Masyarakat yang sebelumnya terikat dengan kekuatan budaya tinggi yang dimiliki, secara perlahan-

6 Graeme Burton, Media dan Budaya Populer, (Yogyakarta- Jalasutra, 2008), hal. 38.

7 Dennis Mc Quail, Teori Komunikasi Massa, (Jakarta: Penerbit Erlangga, 1994), hal. 167.

${ }^{8}$ Onong Uchjana Effendi, Filsafat Ilmu Komunikasi, Teori dan Praktek, (Bandung: Rosdakarya, 2001), hal. 287.

\section{${ }^{9}$ Ibid, hal. 52.}


lahan berubah menjadi komunitas yang tragik, hedonis, dan mengagung-agungkan budaya kekinian/budaya massa. Masyarakat kemudian melihat berbagai persoalan dan dinamika yang terjadi sebagai sesuatu yang relatif dan dalam konteks kebebasan individu. Berkembang wacana bahwa segala yang ada di media adalah budaya yang berlaku umum, dan bisa saja menjadi sebuah pembenaran yang berlaku universal.

Konteks ini tampak pula dalam kegiatan keagamaan. Media massa memegang peranan sentral dalam membentuk opini masyarakat mengenai realitas kehidupan keagamaan yang ada. Seorang da'i yang selama ini belum pernah diperhatikan, kemudian akan menjadi sosok selebritis terkenal, berdasarkan opini yang dibentuk media. Akibatnya, tingkah laku dan aktifitas keseharian sang da'i selalu menjadi sorotan. Da'i itu sendiri kemudian "terjebak" dalam himpitan budaya yang dikembangkan media massa. Contoh konkrit adalah bagaimana fenomena Aa Gym yang pernah menjadi liputan teraktual bagi media massa. Uniknya lagi, kasus poligami Aa Gym ini menjadi sorotan paling besar dari tayangan infotainment. Pertanyaannya, apakah $\mathrm{Aa}$ Gym bisa disejajarkan dengan komunitas selebritis dan artis-artis yang biasa tampil dalam acara tersebut? Apakah tidak mungkin Aa Gym sebenarnya sedang berada dalam pusaran kuat arus dramaturgis yang dikembangkan media? Pertanyaan ini akan bermuara pada konstruksi media terhadap perkembangan pencitraan melalui media massa.

Dalam koridor budaya populer, maka media sebenarnya adalah ranah konstruksi dari berbagai kepentingan. Untuk memainkan kepentingan tersebut, maka pertukaran dan permainan peran menjadi faktor penentu. Pola-pola dramaturgis akan berperanan sekali dan disitulah mekanisme pencitraan dan konstruksi agama sebagai bagian budaya populer berlagsung.

\section{Konsep Dramaturgis dan Paradigma Konstruktivis}

Konsep dramaturgis sebenarnya adalah realitas yang selalu dialami manusia. Hal ini kemudian akan berkolaborasi dengan mekanisme media massa sebagai sarana utama membentuk opini publik. Tidak ada media maupun khalayak yang tidak memainkan peran. Semuanya berada dalam tataran permainan peran yang mengisyaratkan adanya panggung depan dan panggung belakang dari manusia.

Dalam keilmuan komunikasi, maka pola pikir ini berada dalam satu ranah prinsip komunikasi yaitu sebuah proses yang simbolik. Manusia adalah makhluk simbolik. Satu-satunya makhluk yang memproduksi lambang adalah manusia. ${ }^{10} \mathrm{Kemampu-}$

${ }^{10}$ Deddy Mulyana, Ilmu Komunikasi Suatu Pengantar, (Bandung: Rosdakarya, 2001), hal.71. 
an dalam memproduksi simbol ini menjadi khas manusia, dan ini mempertegas bahwa semua ini adalah proses simbolik. Manusia kemudian akan mencoba mengerti makna atau maksud dari suatu aksi yang dilakukan satu dengan yang lain."

Pandangan secara simbolik menegaskan bahwa kemampuan manusia tersebut kemudian menempatkan pula realitas yang ada di sekitar manusia adalah sesuatu yang memang dikonstruksi. Suprapto menyebutkan bahwa semua interaksi antarindividu manusia melibatkan suatu pertukaran simbol. Teori interaksionisme simbolik sendiri menganggap segala sesuatu tersebut adalah virtual. Segala sesuatunya adalah pertukaran dan pemaknaan simbol-simbol yang berlangsung. ${ }^{12}$

Sebuah kata kunci mengenai pandangan interaksionisme simbolik dikemukakan oleh George Herbert Mead yang berkata bahwa diri seseorang terletak pada konsep "pengambilan peran orang lain"(taking the role of the other)". Individu dianggap sebagai sosok yang aktif, yang tidak saja tercipta secara sosial namun juga membuat sebuah dunia baru yang prilakunya tidak bisa diramalkan. Prilaku manusia bersifat sosial dan berbeda dengan prilaku hewan yang hanya sekedar menerima rangsangan dan memberikan respon. Manusia adalah sosok yang aktif dan mampu menciptakan dunia serta kondisi yang diinginkan. Ada kemampuan berpikir dan bertindak yang dimiliki manusia, sehingga membuatnya mampu memainkan peran yang sesuai yang diinginkan. Kemampuan mengambil peran orang lain, sebagaimana dikatakan Mead di atas membuat manusia memiliki kemampuan adaptasi atas dasar interaksinya dengan pihak lain.

Dalam keilmuan sosial, maka konsep ini berawal dari pandangan konstruktivis sebagai sebuah paradigma berpikir. Secara ontologis, paradigma ini memandang bahwa realitas itu ada dalam bentuk bermacam-macam konstruksi mental, berdasarkan pengalaman sosial, bersifat lokal dan spesifik dan tergantung pada orang yang melakukannya. Oleh karenanya realitas yang diamati seseorang tidak bisa digeneralisasi sebagai sebuah realitas yang nyata dan pasti benar. ${ }^{14}$ Pahamnya sangat relatif, sehingga dikatakan bahwa realitas merupakan hasil dari sebuah konstruksi sosial. Kebenaran berlaku sesuai konteks spesifik yang dinilai relevan oleh pelaku sosial ${ }^{15}$

\footnotetext{
"Soeprapto, Interaksionisme Simbolik, (Yogyakarta: Pustaka Pelajar dan Averoes Press, 2002), hal. 22. ${ }^{12}$ Ibid, hal. 141.

${ }^{1}$ George Herbert Mead, Mind Self and Society, (Chicago: University of Chicago Press, 1934), hal.
} 153.

${ }^{14}$ Agus Salim, Teoridan Paradigma Penelitian Sosial, (Yogyakarta: Tiara Wacana, 2001), hal. 141.

${ }^{15}$ Norman K. Denzin, dan Yvonne Lincoln, Handbook of Qualitative Research, (London: SAGE Publication, 1994), hal. 12. 
Fr. Terdapat sebuah pengakuan bahwa dalam kehidupan manusia, sebuah realitas butkănlah sesuatu yang harus dipahami demikian saja, namun ia terbentuk dari sebuah konstruksi yang sengaja diciptakan oleh manusia. Oleh karena itu dalam melihat sẻbtáh kenyataan, harus berawal dari pemaknaan bahwa sesuatu itu tidak terjadi begitu šajâ: Semua realitas harus dimaknai karena ia bisa berada dalam kerangka konstruksi têténtu.

- Pandangan ini mempertegas bahwa tidak ada realitas yang mutlak dan pasti, semuanya menjadi relatif. Kebenaran atas suatu realitas di sebuah wilayah bisa jadi hal yang sebaliknya di wilayah lain. Adanya proses pemaknaan simbolik sangat memưngkinkan untuk terjadinya ragam pemahaman yang berbeda, dan sekaligus masuknya konsep dramaturgis dalam proses memaknai simbol-simbol tersebut.

1.. Menurut teoritisi interaksi simbolik, kehidupan manusia pada dasarnya adalah "interaksi manusia dengan menggunakan simbol-simbol". Beberapa premis yang dikembangkan adalah, pertama, individu merespon suatu situasi secara simbolik. Mereka merespon lingkungan, termasuk objek fisik dan objek sosial berdasarkan makkna yang dikandung komponen-komponen lingkungan tersebut bagi mereka. Kedua, makna adalah produk interaksi sosial, karena itu makna tidak melekat pada öbjèk, melainkan dinegosiasikan melalui penggunaan bahasa. Nama yang digunakan ủntuk menandai objek, tindakan, peristiwa atau gagasan itu bersifat arbitrer (semBarang). Apa saja bisa dijadikan simbol dan karena itu tidak ada hubungan logis antara nama atau simbol dengan objek yang dirujuknya, meskipun terkadang sulit untuk memisahkan hal itu. Ketiga, makna yang diinterpretasikan individu dapat berubah dari waktu ke waktu, sejalan dengan perubahan situasi yang ditemukan dalam interäkśs sosial. Perubahan interpretasi dimungkinkan karena individu dapat melakukan próses mental, yakni berkomunikasi dengan dirinya sendiri. ${ }^{16}$

- iks: Pendekatan simbolik berada dalam ranah paradigma konstruktivis. Paradigma ith menekankan pada konstruksi yang dibangun oleh manusia atas realitas yang terfadi. Semua realitas adalah konstruksi dari manusia. Kata kunci ini menjadi bahan utuma dalam melihat pendekatan interaksionisme simbolik.

Dilithat dari alur dan pecahan teorinya, maka teori interaksionisme simbolik kemudian menjadi cikal bakal munculnya berbagai teori lain. Semuanya tetap dalam kerangka pemahaman bahwa manusia adalah makhluk pemproduksi simbol sehingga bisa menjadi relatif. Salah satu teori yang merupakan pecahannya tersebut adalah teor: Dramaturgis yang digagas oleh Erving Goffman. Konsep dramaturgis menekanIfis?

${ }^{16}$ Dedy Mulyana, Ilmu Komunikasi., hal.73. 
kan bahwa manusia adalah makhluk yang senantiasa memproduksi dan memainkan peran-peran tertentu. Selamanya manusia selalu bermain peran dan tidak ada peran yang bisa dipastikan sebagai sebuah kebenaran atas peran yang dilakukan manusia. Istilah Goffman adalah backstage dan frontstage. Layaknya sebuah panggung sandiwara, manusia selalu bermain dengan tata caranya sendiri dan kemudian bermain sesuai peran yang dimainkannya. Goffman menilai inilah keunikan manusia dan kemudian menjadikannya sebagai makhluk yang senantiasa berubah dan bergerak dengan peran masing-masing. ${ }^{17}$

George Herbet Mead sendiri berkata bahwa diri terletak pada konsep pengambilan peran orang lain. Konsep ini menggambarkan tentang penjabaran diri sosial. Bagi Mead, individu bersifat aktif, inovatif yang tidak saja tercipta secara sosial, namun juga menciptakan masyarakat baru yang prilakunya tidak dapat diramalkan. Mead juga menegaskan bahwa tindakan manusia meliputi bukan saja tindakan terbuka, namun juga tindakan tertutup, mengkonseptualisasikan prilaku dalam pengertian yang lebih luas. ${ }^{18}$ Penegasan Mead ini menjadi sebuah penanda utama bahwa manusia tidak pernah terlepas dari bagaimana mengambil dan mengolah peran dengan orang lain. Inilah sebenarnya kata kunci dari pendekatan dramaturgis.

Secara keilmuan, memang Goffman mendapatkan banyak gagasannya dari pendapat Mead dan Blumer yang menggagas teori interaksionisme simbolik. Inti dari teori dramaturgis adalah menghubungkan tindakan dengan maknanya alih-alih prilaku dengan determinannya. Makna bukanlah warisan budaya, sosialisasi, atau tatanan kelembagaan, atau perwujudan dari potensi biologis dan psikologis, melainkan pencapaian problematik interaksi manusia dan penuh dengan perubahan, kebaruan dan kebingungan. Fokus pendekatan dramaturgis adalah bukan apa yang orang lakukan, apa yang ingin mereka lakukan, atau mengapa mereka lakukan, melainkan bagaimana mereka melakukannya

Sebuah ciri khas prilaku manusia dimana memiliki kemampuan ekspresif sehingga manusia mampu menegosiasikan makna dengan orang lain yang juga ekspresif dalam suatu situasi. Artinya, nasib dan prilaku manusia bukan karena faktor di luar dirinya, melainkan karena akibat tindakan diri mereka sendiri.

Fokus teori dramaturgis bukan pada konsep diri yang dibawa seorang aktor dari satu situasi ke situasi lainnya atau keseluruhan jumlah pengalaman individu, melainkan diri yang tersituasikan secara sosial yang berkembang dan mengatur interaksi-

\footnotetext{
${ }^{17}$ Erving Goffman dalam Dedy Mulyana, Ibid.

${ }^{18}$ George Herbert Mead, Mind Self and Society., hal. 116.
} 
interaksi spesifik. Diri lebih bersifat sosial daripada psikologis. Diri adalah suatu hasil kerjasama yang harus diproduksi baru dalam setiap peristiwa interaksi sosial. ${ }^{19}$

Hal penting dalam teori dramaturgis adalah analisisnya terhadapa kehidupan manusia. Goffman menegaskan bahwa kehidupan ini ibaratkan panggung teater, sebuah pertunjukan yang telah melalui proses pengaturan tertentu. ${ }^{20} \mathrm{Dalam}$ memainkan pertunjukan tersebut, manusia kemudian memainkan peran, berpakaian dan berpenampilan sesuai peran yang diembannya. Goffman kemudian membagi kehidupan sosial manusia itu pada dua wilayah yaitu wilayah depan (front stage) dan wilayah belakang (back stage). Wilayah depan merujuk pada peristiwa sosial yang memungkinkan individu bergaya atau menampilkan suatu peran di atas panggung sandiwara dihadapan khalayak penonton. Wilayah bekalang adalah tempat/peristiwa yang memungkinkan dilakukannya persiapan-persiapan untuk tampil ke depan panggung.

Panggung depan sendiri dibagi lagi oleh Goffman menjadi dua bagian yaitu, personal front (wilayah pribadi) dan setting yaitu situasi yang harus ada ketika kita berada di depan panggung. ${ }^{21}$ Setiap manusia memerlukan setting ini, karena tanpa itu, manusia tidak bisa bersandiwara atau memainkan perannya. Misalnya, seorang dosen memerlukan ruang kuliah untuk tampil dengan peran seorang pengajar. Seorang ustazd memerlukan masjid dan majelis taqlim untuk memainkan perannya. Tanpa itu, kehidupan menjadi tidak ada apa-apanya. Oleh karena itu, panggung dan setting harus dibuat dan dirancang sedemikian rupa sehingga memungkinkan aktor untuk memainkan perannya dengan maksimal.

Pada saat berada di panggung depan, seorang aktor harus bermain peran dengan baik. Ia harus menjiwai peran tersebut agar bisa tampil maksimal dan mendapat predikat sebagai yang terbaik. Seorang ustazd misalnya, ia harus tampil dengan katakata yang ramah, sopan santun, kharismatik, penuh kearifan. Ini syarat utama disamping kemudian dilengkapi dengan kelengkapan busana dan asesoris lainnya. Apabila ia tidak mampu memainkan peran itu dengan baik, maka niscaya ia juga sulit untuk mengukuhkan diri sebagai seorang ustazd. Inilah permainan peran.

Sebaliknya, ketika berada di panggung belakang, seorang aktor akan melepaskan predikat panggung yang tadi dilakoni. Ia bisa saja menggunakan bahasa yang cenderung kasar, buka baju, tertawa lepas, dan sebagainya. Akan tetapi ketika ia berada di panggung belakang pada dasarnya ia juga memainkan peran sendiri yang

${ }^{19}$ Dedy Mulyana, Ilmu Komunikasi., hal. 117.

${ }^{20}$ Ibid, hal. 119. 
berbeda. Ia sebenarnya kembali bermain peran yang lain. Hanya saja ini berbeda dengan panggung pertama di hadapan publik.

Goffman mensinyalir bahwa seorang aktor cenderung untuk melakukan kamuflase terhadap panggung depan. Kekurangan dan kelemahan harus ditutupi, karena ia harus memainkan peran dengan baik. ${ }^{22}$ Identifikasi oleh Goffman adalah sebagai berikut, pertama, aktor mungkin akan menyembunyikan kesenangan-kesenangan tersembunyi yang tidak cocok dengan panggung depan. Kedua, aktor mungkin akan menutupi kesalahan-kesalahan yang terjadi pada saat persiapan di panggung belakang. Ketiga, aktor akan menunjukkan produk akhir dan menyembunyikan proses produksinya. Keempat, aktor mungkin akan menyembunyikan hal-hal negatif dalam persiapan yang dilakukannya. Kelima, dalam melakukan pertunjukannya, aktor harus mengabaikan standar yang lain. Keenam, aktor mungkin perlu menyembunyikan hinaan, pelecehan, atau perundingan yang dibuat sehingga pertunjukan berlangsung baik. ${ }^{23} \mathrm{Pada}$ dasarnya, seorang aktor yang tampil di depan panggung melakukan kamuflase dalam peran yang dimainkannya. Ia memiliki kepentingan untuk menyembunyikan dan melakukan aspek-aspek yang terasa bagus dan menunjang aktingnya.

\section{Melihat Islam di Ranah Populer}

Di awal tulisan ini sudah digambarkan sebuah ilustrasi bagaimana seorang da'i yang berakting di layar kaca. Gambaran tersebut sebenarnya adalah sekelumit aktifitas kegiatan keagamaan Islam dengan menggunakan media massa. Pada penjelasan sebelumnya juga sudah dijabarkan mengenai apa dan bagaimana budaya populer tersebut hadir di tengah masyarakat dan kemudian membentuk sebuah realitas. Telah dijelaskan pula bahwa budaya populer memiliki keterkaitan erat dengan pola-pola dramaturgis yang dimainkan manusia.

Sebuah ilustrasi lain mungkin bisa memberikan pemahaman lebih jauh bagaimana Islam sebagai agama kemudian menjadi sangat pop dan dilihat juga dari perspektif budaya. Ada sebuah ajang adu bakat di televisi yang dikemas dalam acara yang bertajuk Reality Sbow. Program ini lebih menonjolkan adu bakat yang dipertontonkan peserta. Diperlihatkan bagaimana mekanisme awal berlangsung, mulai dari tahapan seleksi hingga kemudian penjurian diatas panggung. Semuanya tidak luput dari sorotan kamera. Seorang peserta adalah perempuan muda, berusia sekitar 17 tahun, berasal

\footnotetext{
${ }^{21}$ Ibid, hal. 123.

${ }^{22}$ Ibid, hal. 115.

${ }^{23} \mathrm{Ibid}$, hal. 116.
} 
dari sebuah desa, ikut tes awal dan masuk seleksi. Kehidupan awalnya yang kental dengan suasana Islami, membuat penampilannya juga identik dengan simbol-simbol Islam. Ia menggunakan jilbab, baju panjang, dan mengikuti arus mode terbaru. Pokoknya orang akan menyebutnya menggunakan busana muslimah. Melihat dirinya orang sudah pasti akan mengatakan bahwa ia adalah Islam. Selanjutnya ia ikut dalam proses, ia ikut bagaimana harus menjalani karantina, pola hidupnya disorot kamera, bagaimana ia makan, tidur dan sebagainya. Di atas panggung ia harus bergaya layaknya seorang penyanyi yang sedang di nilai oleh juri. Ia melenggok, bergoyang, bernyanyi, berduet, tertawa, tersenyum dan tentu saja busana yang memang harus menyesuaikan dengan irama panggung.

Penyanyi tadi menggambarkan dandanan Islami, semua orang menganggap ia Islam. Tak ada yang mengatakan atau berpendapat bahwa apa yang dilakukannya itu sesuai dengan konsep yang betul-betul Islami atau tidak, tak perlu memperdebatkan hal itu. Yang jelas ia mewakili sosok seorang gadis muslim yang bergaya dan berlenggok sesuai tuntutan panggung dan peran yang dimainkan.

Pendekatan dramaturgis melihat hal ini sebagai gejala lumrah dalam proses manusia memainkan peran dan memperlihatkan sosok diri dilakoninya. Dramaturgis seorang artis dadakan akan menyesuikan diri dengan alur cerita yang sudah dibuat. Ia bermain sesuai plot dan arahan yang diminta. Sudah pasti dibelakangnya akan hadir banyak pihak-pihak yang mengarahkan dan menentukan hal-hal apa yang mesti dilakukan oleh si artis tersebut. Ia tidak akan bisa keluar dari jalur yang sudah ditentukan, karena kalau melanggar pakem, tentu peran akan tidak sesuai dengan apa yang diharapkan.

Kondisi yang terjadi di atas sebenarnya adalah perwujudan dari sebuah penggambaran Islam populer di media massa. Islam populer yang dimaksudkan dalam hal ini adalah sebuah kondisi yang memakai nuansa, simbol-simbol keislaman, ataupun punya pesan-pesan bernuansa Islam dengan menggunakan media-media pengusung budaya populer. Pemahaman ini juga membawa pada sebuah pengertian bahwa Islam populer adalah Islam yang dibesarkan media massa, yang selalu terpengaruh oleh gejala-gejala umum yang ada pada media massa. Islam populer adalah Islam yang sudah dibungkus oleh sebuah agenda media dan dikelola oleh sebuah manajemen media.

Berdasarkan pada konteks ini maka dapat dikatakan bahwa gejala yang terjadi selama ini sebenarnya adalah gejala penggunaan media oleh umat Islam (atau tokohtokoh Islam) untuk menampilkan berbagai sikap dan prilakunya. Bisa dalam konteks 
makna penyebaran ajaran-ajaran Islam ataupun bisa juga dalam konteks tampil dengan simbol-simbol Islam, walaupun tidak punya tujuan khusus untuk menyebarkan ajaran Islam. Di sisi lain terdapat pula kemungkinan adanya agenda media yang "memanfaatkan" umat Islam (termasuk tokoh-tokoh Islam) untuk "dijual” sehingga bisa memberikan keuntungan secara material bagi lembaga media massa tersebut.

Beberapa katagori materi di media massa (khususnya media penyiaran) yang bisa kita katagorikan sebagai tayangan bernuansa Islam atau membawa-bawa simbol Islam yaitu:

1. Tayangan sinetron bernuansa Islami.

2. Tayangan talkshow dengan pesan Islam.

3. Tayangan ceramah agama.

4. Tayangan reality show baik yang membawa pesan Islam secara nyata ataupun yang tidak menjadi sajian utama.

5. Tayangan hiburan musik yang menggunakan simbol-simbol Islam.

Dari tayangan-tayangan yang ada selalu menggunakan simbol keislaman. Mengapa Islam begitu menarik? Banyak hal yang menjadi penyebab. Bisa karena komunitas di Indonesia adalah mayoritas Islam atau mungkin bisa juga karena dinamika keislaman di Indonesia yang memang sangat beragam.

Tayangan-tayangan di atas selalu dihadirkan dan diketengahkan ke masyarakat. Yang perlu dicermati bahwa tayangan tersebut kemudian bisa membentuk sebuah pemahaman wajah Islam di Indonesia versi media massa. Versi media kemudian menjadi opini publik dan akhirnya berwujud sebagai kebenaran tentang Islam itu sendiri. Hal ini tentu disayangkan karena realitas menjadi kabur dan sulit dicari kebenarannya.

Jika kita lihat dari perspektif dramaturgis dan konsep budaya populer, maka sebenarnya sudah terjadi pertautan yang erat antara tiga elemen penting yaitu, Islam (diwakili oleh sekelompok orang yang mengaku Islam), media (lengkap dengan agendanya), dan masyarakat itu sendiri. Tiga aspek ini saling berinteraksi dan akhirnya menemukan titik temu melalui media massa, terutama lembaga penyiaran. Jika disingkat pertalian tiga pihak tersebut terlihat dari bagan berikut ini. 
Bagan 1

Tiga Unsur dalam Mengkonstruksi Islam di Media Massa

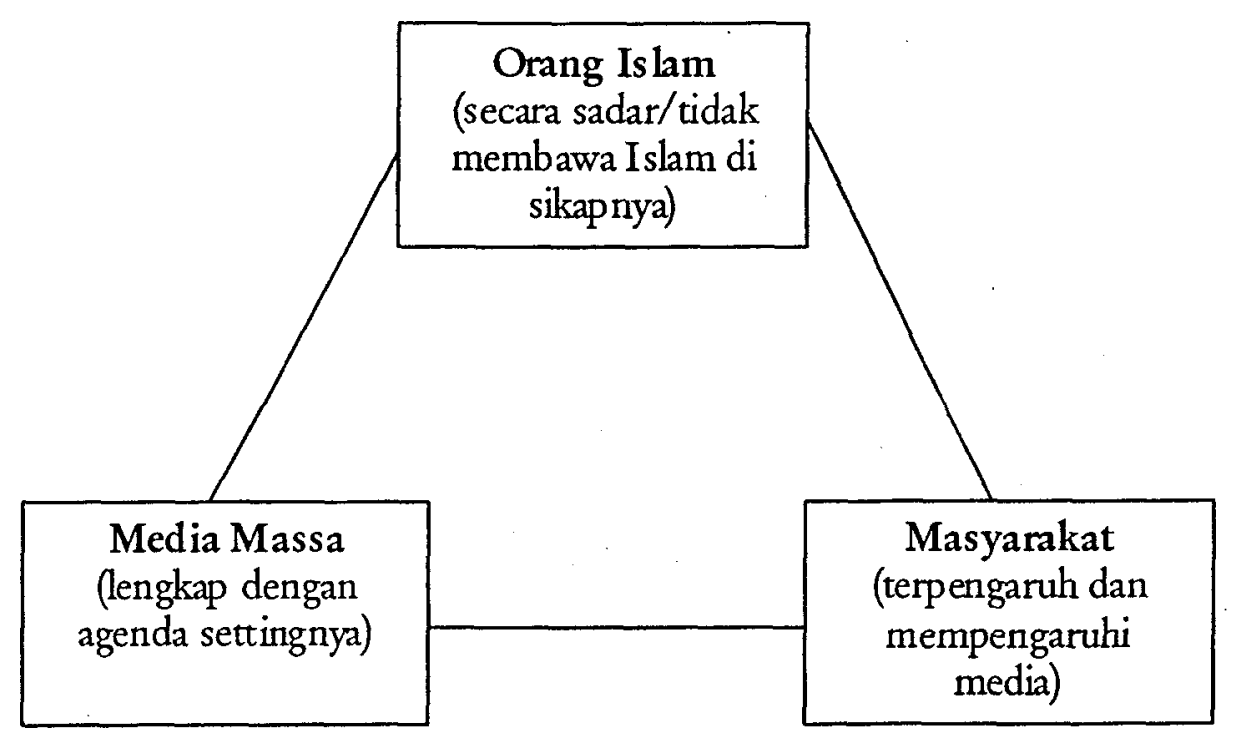

Gambaran di atas memperlihatkan sebuah pola hubungan yang sangat erat dan saling mempengaruhi antar semua unsur. Sebagian umat Islam, terutama yang terlibat dalam media, memerlukan media massa sebagai panggung untuk menunjukkan eksistensinya (dilain pihak juga sering terdengar alasan untuk syiar Islam). Mereka membutuhkan panggung, dan panggung yang paling baik, paling cepat ditangkap, paling mudah diingat khalayak adalah media massa. Tak heran, baik secara sadar maupun tidak sadar sebenarnya mereka sudah berada dalam sebuah setingan panggung media, sebuah show yang tentu memerlukan berbagai upaya rekayasa.

Kebutuhan akan panggung tersebut direspon oleh media massa, bahwa mereka memiliki jawaban itu. Lewat kekuatan infrastruktur yang tentu saja padat modal, media menyediakan akses yang demikian luas untuk diketahui publik. Apakah dalam posisi ini media bersikap netral dan objektif? Tentu tidak bisa dilepaskan bahwa pada media juga terdapat kepentingan tersendiri, bisa saja itu kepentingan bisnis, politik, ideologi dan lain sebagainya. Inilah yang kemudian mewujud dalam agenda media. Agenda ini kemudian dikonkretkan melalui sebuah upaya rekayasa realitas, sebuah konstruksi kenyataan. Yasraf Amir Piliang menyebutnya sebagai sebuah permainan realitas berupa simulacrum-simulacrum yang diciptakan oleh media. ${ }^{24}$

${ }^{24}$ Yasraf Amir Piliang, Posrealitas., hal. 51. 
Sementara di sisi lain, masyarakat sendiri membutuhkan sesuatu yang berbeda dari yang ditemukan sehari-hari. Ini sebenarnya prilaku yang manusiawi, dimana manusia tertarik pada sesuatu yang baru, aneh, dramatis, dan bisa memainkan emosi. Lumrah sekali manusia tertarik pada hal ini. Ketika media mengkonstruksi realitas tersebut dan menciptakan suasana yang sedemikian rupa, ketertarikan publik muncul. Acara keagamaan yang biasanya hanya monoton atau memperlihatkan seorang penceramah memberi wejangan kepada jamaah, sekarang berubah menjadi setingan tertentu. Acara tausyiah keagamaan harus dibarengi dengan isak tangis, harus ada ketawa dan sebagainya. Ini adalah kesan yang begitu dramatis, dan semua itu diciptakan.

Dapat kita amati, bahwa ketika seorang penceramah agama Islam hadir di layar kaca dengan gaya dan dandanan khas, maka ia sebenarnya sudah memainkan sebuah peran dramaturgis. Ia akan berperan sebagai seorang Ustazd yang tampil di layar kaca, disaksikan orang di seantero negeri. Jamaahnya bukan lagi satu masjid atau satu lapangan, tapi seluruh negeri. Apa maknanya? Terjadilah proses mengaktualisasikan diri dengan bersikap sempurna dan melakukan kamuflase-kamuflase tertentu. Media massa tentu saja tidak ingin sesuatu yang monoton dan tidak ada "percikan". Karena itu perlu diciptakan dan dikonstruksi situasi yang dramatis, membius dan mendatangkan ketertarikan penonton. Pada posisi ini sebenarnya Ustazd dan kalangan tokoh Islam lainnya bukan lagi sebagai seorang subjek namun juga menjadi objek.

Dalam konteks ranah media populer, apa yang terjadi tersebut adalah sesuatu yang lumrah karena memang harus seperti itu. Persoalannya adalah bagaimana masyarakat merespon itu sebagai sebuah permainan peran. Ini adalah tugas semua kalangan untuk menegaskan bahwa segala yang ada di media massa, pencitraan yang terjadi adalah sebuah permainan peran dari sekelompok pihak yang berkepentingan. Artinya, pada sisi lain akan terjadi pertukaran peran dan itu harus juga dimaknai dalam konteks dunia populer.

Akan sangat berbeda diberikan pemahaman jika realitas yang terjadi tersebut dianggap sebagai realitas yang sebenarnya dan kemudian diadu dengan kerangka ideologi yang dimilikinya. Sebagai contoh, ketika terjadi keributan di Monas antara massa FPI dengan massa AKKBB, media massa menayangkannya berulang kali dengan menekankan pada prilaku keras dari FPI. Jika ini ditangkap sebagai realitas ansich maka disitulah kekeliruan terjadi. A pa yang tampak di media adalah sebuah kumpulan potongan fakta-fakta yang dikumpulkan oleh media dan disuguhkan kepada khalayak. Media menjadi panggung sekaligus sutradaranya, dan para massa FPI serta AKKBB adalah aktor-aktor yang disorot oleh kamera dan akting mereka dibuat sedemikian rupa. 
Dalam pandangan Roger Fidler ini disebut dengan mediamorphosis atau berubah-rubahnya media. ${ }^{25}$ Transformasi media komunikasi adalah sebagai akibat dari interplay rumit dari kebutuhan-kebutuhan yang dibayangkan, tekanan-tekanan kompetitif dan politis, dan inovasi-inovasi sosial dan teknologis. Pada sisi lain, media massa kemudian berpengaruh terhadap perubahan sikap, wawasan, prilaku masyarakat.

Indikasi terjadinya pertautan antara media massa, umat Islam, dan pencitraan yang terjadi, sebenarnya tidak lepas dari fenomena yang didalam media populer di sebut dengan "paradigma mimpi" . ${ }^{26}$ Manusia selalu punya angan-angan, harapan, mimpi. Hal ini kemudian dijembatani oleh media, sehingga mimpi itu bisa "seolaholah" terwujud. Dalam posisi ini, media dianggap sebagai broker mimpi masyarakat, mendorong publik agar selalu bermimpi dan kemudian dicoba peruntungan mewujudkannya. Konteks Islam di media massa tetap sama dalam perlakuan ini. Umat Islam sendiri juga didorong dan senantiasa bermimpi tentang berbagai prilaku kehidupan yang lebih bebas namun tetap dalam kerangka simbol-simbol Islam. Para Ustazd juga didorong agar bisa tampil sepopuler mungkin, agar para Ustazd tersebut punya nilai jual, tidak hanya dari sisi materi ceramah namun juga dari sisi performance dan entertainment.

Televisi diharapkan bisa bermain peran yang lebih baik. Pareno berkata bahwa sebenarnya kita juga bermimpi bahwa televisi bisa menjadi media dakwah. ${ }^{27}$ Sayangnya di televisi selalu sarat kepentingan kekuasaan, politik, ekonomi, militer, dan sebagainya. Pada saat itu televisi sebenarnya sudah bukan media massa lagi, tapi sudah menjadi alat propaganda pihak tertentu, terutama dalam menyebarkan budaya populer.

Dalam ranah media populer yang ditayangkan di televisi, Islam juga menjadi sesuatu yang serba instan. Tidak perlu lagi ada pola-pola yang dikatakan, "berakitrakit ke hulu, berenang-renang ke tepian," semuanya bisa diselesaikan dengan sekejap. Inilah yang bisa dilihat ketika sebuah televisi membuat tayangan "Da'i Cilik". Dengan mengumpulkan anak-anak dalam jumlah tertentu, mengkarantinanya, melatih dan menyuruhnya menghapal teks-teks ceramah, maka dalam kurun waktu tak lebih dua bulan, ia sudah menjadi Da'i yang kondang di televisi. Ini fenomena instan.

Menurut Pareno fenomena instan merupakan antitesis dari fenomena yang mungkin dianggap ruwet dan bertele-tele. ${ }^{28}$ Fenomena ini boleh jadi disebut sebagai

${ }^{25}$ Roger Fidler, Mediamorphosis, (Yogyakarta: Penerbit Bentang, 2003), hal. 189.

${ }^{26}$ Sam Abede Pareno, Media Massa antara Realitas dan Mimpi, (Surabaya: Penerbit Papyrus, 2005), hal. 166.

\footnotetext{
27 Ibid, hal. 167.

${ }^{28}$ Ibid, hal. 173.
} 
tuntutan sejarah dan atau keharusan sejarah sebagai sebuah realita yang mesti dijalani. Pada beberapa sisi memang fenomena instan mendatangkan efek positif, namun disisi lain ia berpotensi melemahkan proses sebelumnya yang sebenarnya sudah melembaga. Termasuk dalam konteks ajaran Islam, fenomena ini berpotensi melemahkan kelembagaan-kelembagaan lain yang berperan dalam membentuk pola pikir keislaman yang mapan.

Sekali lagi, dalam ranah dunia populer, ketika Islam masuk ke sana dan bermain dalam lingkaran tersebut, maka semuanya harus dipandang dalam konteks ranah populer. Ciri khasnya jelas, ia selalu mengikuti trend dan gampang berubah sesuai selera media dan pasar. Tak ada ideologi di situ, karena semuanya bermain peran dan saling memperlihatkan peran yang dilakoni. Rekayasa panggung dan tuntutan cerita dalam teks skenario ikut menentukan dan itulah yang kemudian disuguhkan kepada publik. Singkat cerita, Islam di media massa adalah realitas Islam yang sudah direkonstruksi dan diciptakan ulang. Tak ada yang mutlak di situ, semuanya menjadi sangat relatif.

\section{E. Penutup}

Terlihat sebuah gejala umum bahwa penggunaan sarana media populer belakangan ini adalah sebuah kondisi yang memang dibutuhkan. Semua ini sudah menjadi tuntutan zaman dan kebutuhan manusia. Islam sebagai agama dakwah dengan komunitas terbesar di dunia, memerlukan panggung dan juga dimanfaatkan oleh berbagai pihak untuk tampil ke atas panggung dan memainkan peran-peran tertentu. Imbalannya adalah ketenaran dan kepopuleran, inilah budaya populer. Islam berada dalam dunia tersebut dan realitas itu terus terjadi. Harus dipahami bahwa dunia populer adalah dunia yang senantiasa berubah dan tidak memiliki ideologi yang menjadikannya kekal. Semua yang ditampilkan adalah proses rekonstruksi dan rekayasa tayangan yang mengaburkan realitas sebenarnya. Ketika Islam masuk dalam ranah populer, maka ia sudah dipoles, diolah dan dijadikan komoditas panggung. Bahwa itu memiliki efek positif kepada masyarakat, memang betul, namun di sisi lain ia juga memiliki efek negatif yaitu melemahkan gagasan-gagasan fundamental yang sebenarnya merupakan inti dari pemahaman beragama. 
128 Millah Vol. IX, No. 1, Agustus 2009

\section{DAFTAR PUSTAKA}

Burton, Graeme, Media dan Budaya Populer, Jalasutra, Yogyakarta, 2008

Denzin, Norman K dan Yvonne Slincoln, Handbook of Qualitative Research, SAGE Publication, London, 1994

Effendi, Onong Uchjana, Filsafat Ilmu Komunikasi, Teori dan Praktek, Rosdakarya, Bandung, 2001

Fidler, Roger, Mediamorphosis, Penerbit Bentang, Yogyakarta, 2003

Haryanto, Ignatius, Aku Selebriti, Maka Aku Penting, Penerbit Bentang, Yogyakarta, 2006

Lippman, Walter, Public Opinion, Free Press, New York, 1965.

Mc Quail, Dennis, Teori Komunikasi Massa, Penerbit Erlangga, Jakarta, 1994

Mead, George Herbert, Mind Self and Society, University of Chicago Press, Chicago, 1934

Mulyana, Deddy, Ilmu Komunikasi Suatu Pengantar, Rosdakarya, Bandung, 2001

Pareno, Sam Abede, Media Massa antara Realitas dan Mimpi, Penerbit Papyrus, Surabaya, 2005

Piliang, Yasraf Amir, Posrealitas, Jalasutra, Yogyakarta, 2003

Rivers, William dan Jay W Jensen, Media Massa dan Masyarakat Modern, Prenada Media, Jakarta, 2003

Salim, Agus, Teoridan Paradigma Penelitian Sosial, Penerbit Tiara Wacana, Yogyakarta, 2001

Strinati, Dominic, Popular Culture, Pengantar Menuju Teori Budaya Populer, Penerbit Bentang, Yogyakarta, 2003

Soeprapto, Riyadi, Interaksionisme Simbolik, Pustaka Pelajar dan Averoes Press, Yogyakarta, 2002 